\title{
Plant and Sheep Production on Semiarid Annual Grassland in Israel
}

NAPHTALI H. TADMOR, EZRA EYAL, AND ROGER W. BENJAMIN

Highlight: A stocking rate experiment with sheep was carried out over a 12-year period, 1962-1973, in a semidesert area with $250 \mathrm{~mm}$ rainfall. Four pasture types were investigated. Site and experimental conditions are described in this paper as well as grazing results on the unimproved native grassland. This is a herbaceous sward composed entirely of annuals. It yielded between 2 and 4 ton/ha dry matter per year in accordance with rainfall fluctuations. These yields are high in comparison with records from other parts of the world. It was shown that this area could give unsupplemented year round support to Mutton Merino sheep at stocking rates of 0.6-1.0 hectare per sheep per year. Annual lamb production ranged between $20-30 \mathrm{~kg}$ per ewe and between 30-60 kg per hectare. This is the first report of lamb production in such a low rainfall area.

The wide arid belts that border the North African and Middle Eastern deserts have had nomadic populations since ancient times. The $150-350 \mathrm{~mm}$ rainfall belt is the border between the desert and the sown. The climate there is extremely variable (Butzer, 1951). Interseasonal rainfall variations, in a ratio of 10:1, are the result of changes in major upper level synoptic conditions (Levi, 1963). Human settlement in this area has been traditionally unstable since Biblical times: "Then Isaac sowed in that land, and received in the same year a hundredfold." (Genesis 26:12). On the other hand: "And there was a famine in the land, and Abram went down into Egypt (i.e., the irrigated lands) to sojourn there; for the famine was grievous in the land" (Genesis 12:10). The total dependence of the farmer on the seasonal rains has been stated dramatically in the Bible: "The land which you are entering... is not like the land of Egypt... where, after sowing your seed, you irrigated it by foot like a vegetable garden. But the land into which you are crossing is ... watered by the rains of heaven" (Deutoronomy 11:10-11).

For the last 1300 years, nomads have subsisted on marginal grain cropping for human consumption with very low grain yields $(200-700 \mathrm{~kg} / \mathrm{ha})$, necessitating traditional government handouts in drought years. As a marketable produce, as well as

At the time of the research, authors were professor of plant ecology, Botany Department, Hebrew University, Jerusalem, Israel; head of Division of Sheep, Agricultural Research Organization, Beit-Dagan; and range officer and manager of the Migda site, Gilat Experiment Station near Be'er Sheya, Israel, Naphtali Tadmor has since passed away.

The study is a contribution from the Agricultural Research Organization, Israel, 1973 Series No. 262-E.

This project was carried out by a team of researchers and technicians. Those active in certain aspects included, besides the authors, N. Seligman, M. Guttman, S. J. Ellern, P. Yonatan, and Y. Ast of the Agricultural Research Organization; M. Vachnish of the Faculty of Agriculture; M. Forti, A. Degen, and the late M. Morag of the Negev Institute of Arid Zone Research; B. Yogev, A. Brigitt; H. Takhan, Salim, and Suleiman Aldanfiri of the Ministry of Agriculture; L. Shanan, consulting water engineer; and $H$. van Keulen and $C$. T. de Wit from the Agricultural University of Wageningen, as well as numerous students. Without the splendid teamwork and help of people from many disciplines this project could not have been undertaken.

Manuscript received November 30,1973. a sign of wealth, flocks-mostly goats and sheep-were raised. In "good" (high rainfall) years the flocks grazed the uncultivatible arid wastelands of the $100-350 \mathrm{~mm}$ rainfall belt. In drought years, or in the dry season, grazing traditionally necessitated wide nomadic movements. Modern agricultural systems and high standards of living-whether real or only expected-no longer make these movements possible. Besides, political reality and modern land tenure systems restrict the shepherd as well as the farmer to definite plots.

In spite of these constraints, sheep are potential producers of protein from the desert. Survival and production in hot dry conditions from low quality sparse pasture is due primarily to the sheep's ability to withstand dehydration (Purohit et al., 1972), heat (Lyne et al., 1970), and extreme fluctuations in feed availability, and to quickly recover from starvation and dehydration. To be economically productive, desert sheep must also have reasonable fertility, lactational potential, satisfactory growth rate, and carcass quality. In many countries, modern dry land farming integrates grain cropping and livestock production into one single farm system (Rossiter, 1966). Under this system, the farmer owns cropland, pasture-and sheep. In "good" years, a grain crop is harvested. In these years the pasture will be plentiful and sufficient for the sheep. In "drought" years the grain is unharvestable. The pasture also will be insufficient. In such years, the drought-failed grain is a welcome high-yielding complement to the pasture, allowing the farmer to keep his flock alive, on his own land, without buying costly outside feeds and without society-disrupting migration. Such an operation, essentially an adaptation of ley farming to arid conditions, turns separate losses from sheep and grain in a drought year into a profit. This makes the long-term grainsheep operation in a variable climate profitable where grain farming or sheep alone would be a failure, and leads to sociological and political stability. The inclusion of livestock thus allows grain farming to be pushed more and more into "marginal" lands.

With the fast-rising standard of living that followed the establishment of the State of Israel in 1948, traditional grain-farming in this arid belt soon became untenable. It was first supported by a farmers' drought-insurance system at a high annual cost to the taxpayer. It soon became apparent that where irrigation water was insufficient to irrigate large parts of a farm, alternative systems of dryland-farming had to be found. This led, in 1962, to a series of experiments. The course and results of these experiments may be of relevance not only to Israel but to large parts of the Middle East and other countries of similar climate.

The present communication includes a general description of the experimental site, of the methods used, and the results obtained on the unimproved native pasture of the area.

\section{Migda Experimental Site}

This arid grazing land project has been carried out over 12 years, 1962 to 1973 , at the Migda Experimental site $\left(34^{\circ} 25^{\prime}\right.$ 


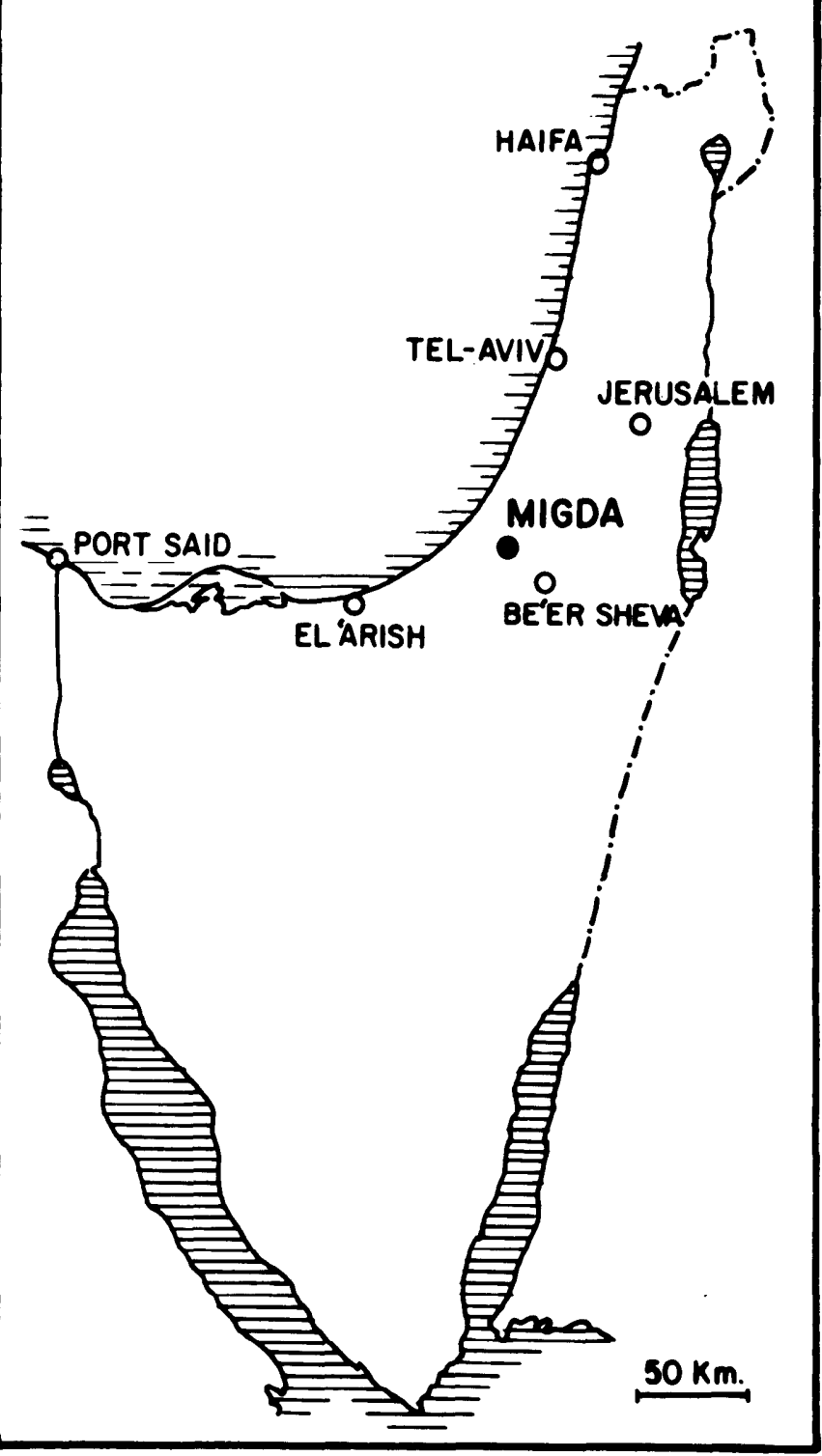

Fig. 1. Map of Israel showing location of the Migda Experimental Site.

long., $31^{\circ} 22^{\prime}$ lat., $100 \mathrm{~m}$ altitude a.s.1.) near Beersheba in the Northern Negev desert of Israel (see Fig. 1).

\section{Climate}

This is a winter rainfall area with rain coming between October and April; $60 \%$ of the annual precipitation is concentrated in December and January. Due to the Mediterranean climatic seasonality, rainfall and growing seasons are always referred to as $1962 / 63,1963 / 64$, i.e., from October 1962 to September 1963 , etc. There are extreme rainfall fluctuations between years $-42 \mathrm{~mm}$ in $1962 / 63,412 \mathrm{~mm}$ in 1964/65-but without discernible periodicity. Long-term (110 years) cycles seem to exist with 20 years moving averages reaching $20 \%$ above and below the long-term mean (Shanan et al., 1967). The pattern of rainfall distribution within a single season greatly influences vegetation development. Temperatures are mild in winter. The coldest month is January with mean minimum, daily mean, and mean maximum temperatures of $7.6^{\circ} \mathrm{C}, 12.6^{\circ} \mathrm{C}$ and $18.1^{\circ} \mathrm{C}$. There are 20 to 30 nights of frost, with the soil surface temperature dropping to -1 to $-4^{\circ} \mathrm{C}$. Temperatures are high in summer. The hottest month is August with mean minimum, daily mean, and mean maximum temperatures of $20.2^{\circ} \mathrm{C}, 26.8^{\circ} \mathrm{C}$ and $33.5^{\circ} \mathrm{C}$.
Soil

The soil is a deep sandy loam (loess) plain 10-20 m deep. Soil physical constants (moisture retention curve) are given in Figure 2. "Field capacity" is about $16 \%$ per weight and "wilting point" about 5\%. Bulk density is 1.35 . This gives an available moisture range of $11 \%$ per weight or $15 \%$ per volume-i.e., $150 \mathrm{~mm}$ of available water are temporarily stored per meter depth. This equals $1501 / \mathrm{m}^{2}$ or $1500 \mathrm{~m}^{3} / \mathrm{ha}$. In this $250-\mathrm{m}$ rainfall area, wetting thus is usually not deeper than $150 \mathrm{~cm}$ and soil moisture seldom exceeds the rooting depth of the annual vegetation. On the impact of rain drops, this structureless loam forms a crust (Hillel, 1969) and infiltration decreases rapidly to $3.4 \mathrm{~mm} /$ hour (Tadmor and Shanan, 1969). This causes runoff on even slight slopes.

On flat land, most of the runoff from $1 \mathrm{~m}^{2}$ accumulates in slight depressions of an adjoining square meter. Runoff and "run on" thus seem to be a major source of the enormous spot-to-spot variation in vegetation development characteristic of the area.

\section{Pasture Vegetation}

The native vegetation is an abandoned cropland vegetation, consisting predominantly of herbaceous annuals. The grasses, Brachypodium pinnatum, Elymus geniculatus, Hordeum murinum, Phalaris paradoxa, Stipa capensis; the legumes, Medicago polymorpha and Trigonella arabica; the crucifers, Erucaria boveana and Reboudia pinnata, and the compositae, Anthemis melaleuca and Centaurea iberica, are the predominant plants. Seasonal development of this vegetation (Fig. 3) depends wholly on the rains. Before the rains start, grazed areas may be completely bare. After the onset of rains

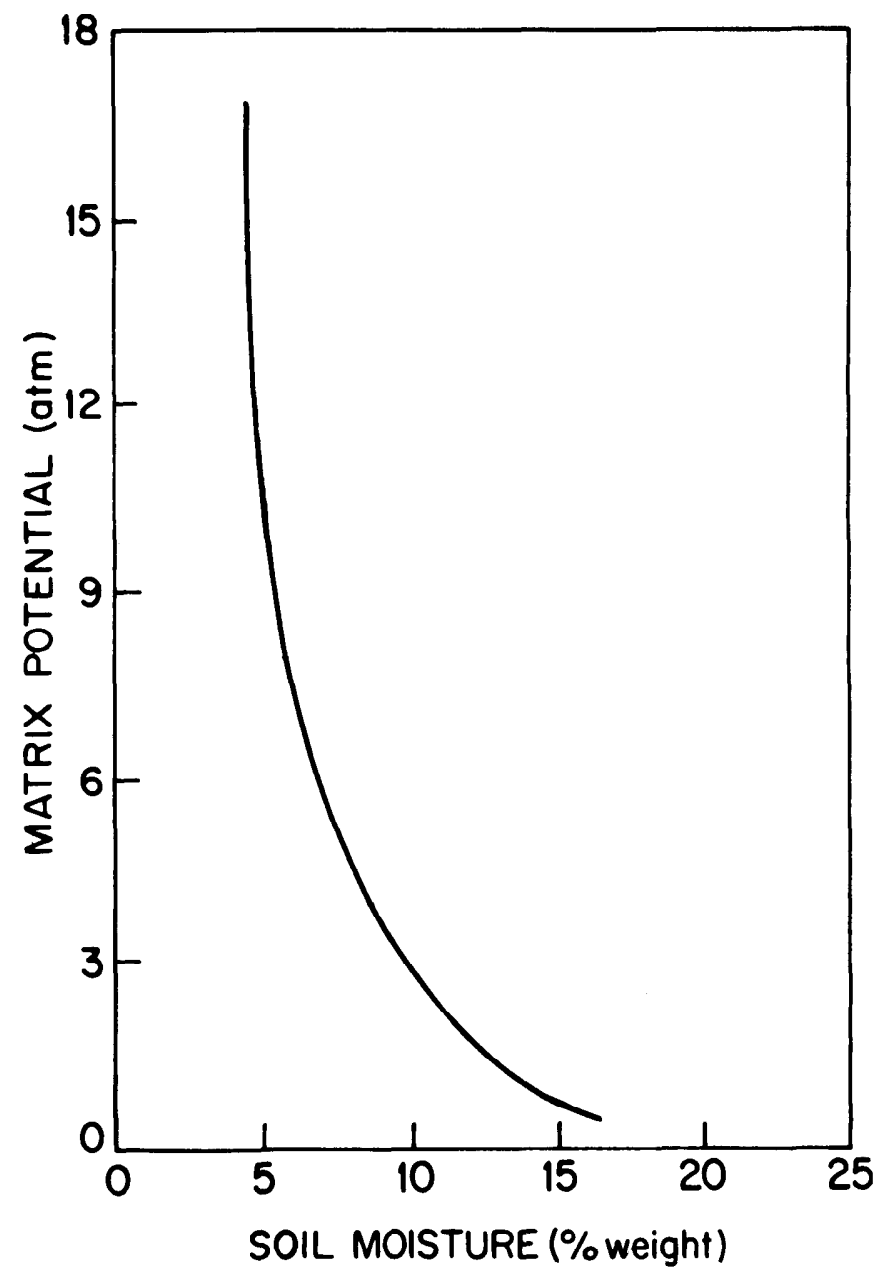

Fig. 2. Soil moisture retention curve, Migda sandy loam soil. 

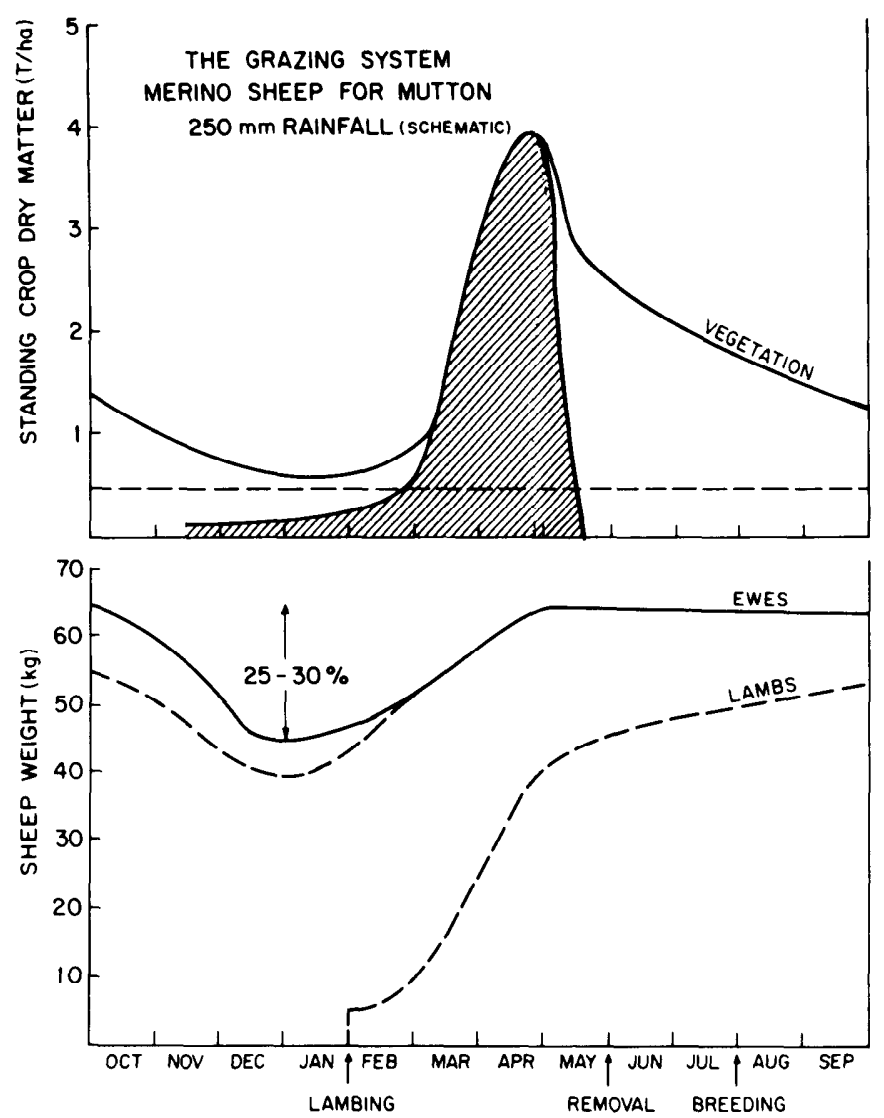

Fig. 3. (Upper) Seasonal development of annual pasture in Migda. Stripped area denotes green forage. During the rest of the year vegetation is stem-cured hay. (Lower) Ewe weight fluctuations and lamb development adapted to the forage seasonality. Both parts are semischematic abstractions as extreme variation occurs between years.

between October and November, germination and emergence take place after 5-15 days, depending on temperature, when about 150 days/degrees have been reached (Tadmor et al., 1968). The density may at first be about $500-700$ seedlings $/ \mathrm{m}^{2}$, and with successive rains it increases gradually to $3000-5000$ seedlings $/ \mathrm{m}^{2}$. Vegetation development is very slow in cold December and January. When there are no early October rains, the soil may stay relatively bare till mid-February. With rising temperatures in February, vegetation development is gradually accelerated and may reach peak growth rates of $17 \mathrm{~g} / \mathrm{m}^{2} /$ day (i.e., $170 \mathrm{~kg} / \mathrm{ha} /$ day) in March, if soil moisture permits. The period of plant development varies from 5 weeks to 5 months between November and March, depending on the seasonal rainfall. In late spring (March-April) peak dry matter yiclds of $200-400 \mathrm{~g} / \mathrm{m}^{2}$ (2-4 ton $/$ ha dry matter) are reached. The vegetation then dries up and remains as stem-cured hay until decomposing the following winter. Directly after maturing, a $20-30 \%$ decrease of standing crop occurs, due to seed scattering and physical breaking up of leaves. Gradual weathering continues during summer, a process not yet well understood but perhaps due to grasshopper and vole activity.

\section{Materials and Methods}

\section{Experimental Layout}

The project described in this paper was designed as a stocking rate experiment on the four main pasture types of the region. Subsequently, it developed also into an arid ecosystem study and as a validation site for crop and pasture growth models. Of the area described, 200 ha (about 500 acres) were fenced and then subdivided into first 18 , then 42 subplots of 0.1 to 12 hectares size, each grazed at different stocking rates.
Three vegetation types were artificially established in part of the plots and were compared to the above described annual native vegetation. These types were: seeded legumes; wheat and/or barley seeded for pasture; and planted salt bush. They form with native pasture the four main blocks of the experiment.

\section{Establishment - 1962-1964 (2 years)}

The experimental area was subdivided and fenced, soil and vegetation surveys were carried out; legumes, barley, oats and wheat sown and salt bush planted. Water supply was installed, as well as runoff-plots. Vegetation measurements were carried out.

\section{Preliminary Grazing (Phase I) - 1964-1967(3 years)}

Sheep were introduced and a preliminary series of grazing experiments were carried out with stocking rates of 0.6 and $1.2 \mathrm{ha} / \mathrm{sheep}$ under year-round grazing. During this phase it became apparent that possible stocking rates were closer to the higher rate. This formed the basis for the planning of the main phase. Both disturbed and undisturbed plant development and secondary production were monitored in this first phase.

Main Grazing (Phase II) - 1967-1972 (5 years)

This was the main experimental period. Six stocking rates were applied to each vegetation type, ranging from 0.2-1.0 $\mathrm{ha} /$ sheep in the native pasture.

\section{Sheep}

Closed flocks of breeding ewes were maintained throughout each phase of the experiment. Fixed numbers of sheep (6-20) were kept in fenced paddocks. Yield was measured annually in terms of lamb production with wool a secondary product. Yields were calculated on a per ewe and per land area basis. German Mutton Merino hoggets (yearlings) were introduced in $1964 / 65$ and used for both grazing phases on the native pasture. There were 12 ewes in each plot (10 adult and 2 hoggets) kept as closed flocks. Replacements were made as necessitated by deaths or by management or breeding requirements, resulting in occasional small deviations in the flock composition of a plot in a certain year (e.g., 11 ewes and 1 hogget, or 9 ewes and 3 hoggets). All calculations were related, however, to a number of 12 ewes. Sheep were kept outdoors throughout the years. New lambs born in each plot were used as replacements for culled animals and natural death. The breeding seasons commenced at the middle of August so that lambing would coincide with the beginning of pasture growth (Fig. 3). An artificial (milk) feeder system was introduced to save lambs born when vegetation was insufficient to support ewe milk production. No supplementary concentrates were given throughout the years except during late pregnancy in the $1966 / 67$ drought. When sheep reached the "crashing point" towards the end of the season on the high stocking rate plots, the animals were removed to reserve plots and maintained at the same body condition until the onset of the next season. In these cases, sheep production figures were corrected to that fraction of the year during which grazing actually took place.

\section{The Measurement System}

The following measurements were carried out at the Migda site:

\section{Climate}

Rainfall was measured in 28 rain gauges, 4 recording rain gauges and 24 small orifice tube-gauges, all well dispersed over the experimental area.

Temperature was recorded by a thermohydrograph and maximum-minimum thermometers at the nearby $(8 \mathrm{~km})$ Gilat 


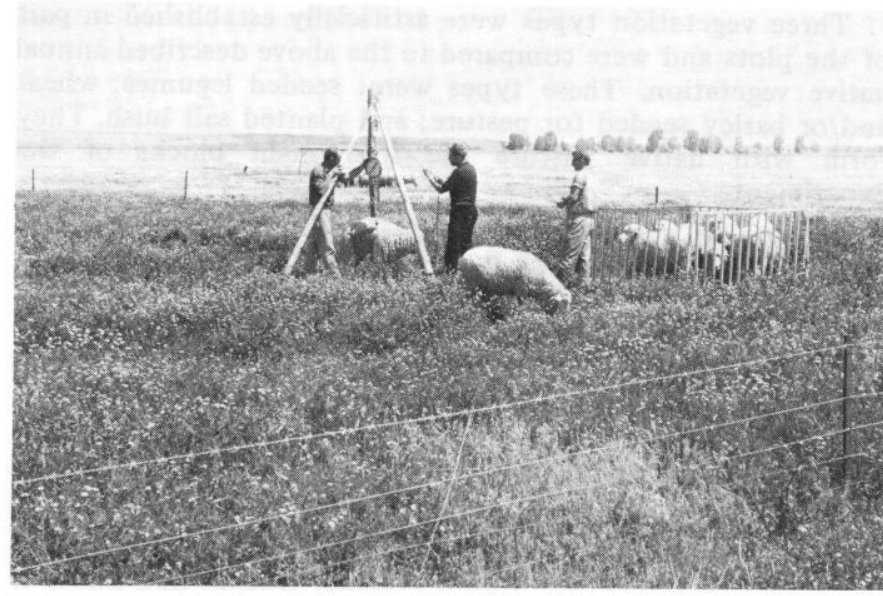

Fig. 4. Weighing Mutton Merino sheep in the corner of a "legume" field, in the spring of a "good" year (280 mmofrain with good distribution). The native pasture in the background is dominated by the white flowers of Trigonella arabica and Anthemis melaleuca. (Note the light aluminum hurdles used to enclose the sheep.)

Experiment Station in the same topographic conditions. Soil temperatures were recorded $25 \mathrm{~km}$ away in Beersheva in an identical soil type by the Meterorological Service.

Radiation, humidity, evaporation (class A pan), wind, and cloudiness were all recorded daily in Gilat.

\section{Soil Water Balance}

Thirty small runoff plots $\left(5-80 \mathrm{~m}^{2}\right)$ measured runoff of bare soil, vegetation covered soil, and under various soil surface treatments (Tadmor and Shanan, 1969). Two plots were equipped with simultaneous rainfall and hydrograph recorders which plot rain and runoff intensity on the same chart.

Soil moisture changes were monitored (since 1971) by Neutron moderation in 250 access tubes at a depth of 220-240 $\mathrm{cm}$ every 2 weeks and after each rainfall in the growing season and every 3-4 weeks in the dry summer. Soil surface moisture was measured gravimetrically every 1-2 days directly after a rainfall and then weekly till the next shower.

Soil surface evaporation was measured by gravimetric sampling from bare plots.

\section{Plant Biomass and Production}

Germination and seedling survival studies of the major plants were carried out in the laboratory (Tadmor et al., 1963-71).

Plant biomass (above ground) was sampled at first periodically and since $1970 / 71$ at 2 -week intervals in the growing season, and 4 to 5 -week intervals in the dry season. Sampling was done by clipping above-ground biomass to the ground in representative samples (10-40 per plot). Since 1971/72, a double sampling technique was employed. Biomass was estimated visually (dry matter or fresh weight) in a large number of quadrats ( 400 per plot). This estimate is calibrated by harvesting a subsample of 10-40 quadrats. The resultant regression (linear or logarithmic) is excellent, with $r=0.96$ to 0.97 obtained by trained technicians. This large scale, nondestructive sampling was found to be well suited to the annual, highly heterogenous herbaceous sward.

\section{Animal Population}

All ewes were weighed 3 days after lambing, at the end of the green pasture season, at shearing and several times (at 4 to 5 week intervals) during summer and autumn. Occasionally the whole flock was weighed also in other seasons. Lambs were weighed at birth, at fortnightly intervals until weaning, and at
Table 1. Rainfall (mm), peak yields (ton/hectare) of "native" vegetation and dry matter production $(\mathrm{kg})$ per $\mathrm{m}^{3}$ of rainfall.

\begin{tabular}{|c|c|c|c|c|}
\hline \multirow[b]{2}{*}{ Year $^{1}$} & \multirow[b]{2}{*}{$\begin{array}{l}\text { Amount } \\
\text { of rain }\end{array}$} & \multicolumn{2}{|c|}{ Yield of native vegetation } & \multirow{2}{*}{$\begin{array}{c}\text { Dry matter } \\
\text { production } \\
\text { per } \mathrm{m}^{3} \text { of rainfall }\end{array}$} \\
\hline & & Fresh matter & $\begin{array}{c}\text { Dry } \\
\text { matter }\end{array}$ & \\
\hline $1962 / 63$ & 42 (b) & no germination & 0 & 0 \\
\hline $1963 / 64$ & $377(\mathrm{~g})$ & 13.4 & 3.4 & 0.9 \\
\hline $1964 / 65$ & $413(\mathrm{~g})$ & 10.4 & $3.1^{3}$ & 0.7 \\
\hline $1965 / 66$ & 218 (b) & 10.3 & 3.0 & 0.7 \\
\hline $1966 / 67$ & $282(\mathrm{~g})$ & 15.9 & 3.6 & 1.3 \\
\hline $1967 / 68$ & 308 (b) & 11.3 & 2.8 & 0.9 \\
\hline $1968 / 69$ & 224 (b) & 9.4 & 2.6 & 1.2 \\
\hline $1969 / 70$ & 170 (b) & - & 0.9 & 0.5 \\
\hline $1970 / 71$ & 238 (b) & 4.6 & 1.1 & 0.5 \\
\hline $1971 / 72$ & $350(\mathrm{~g})$ & 6.6 & $(3.6)^{4}$ & 1.6 \\
\hline $1972 / 73$ & $258(\mathrm{~b})$ & - & 3.5 & 1.4 \\
\hline
\end{tabular}

${ }^{1}$ In this winter rainfall area, the agricultural year is considered from October of one year to September of the following year, hence $1962 / 63,1963 / 64$, etc.

${ }^{2}(\mathrm{~g})$ for good intraseasonal distribution, (b) for bad.

${ }^{3}$ After effect of no grazing in $1963 / 64$, resulting in decomposition of large amounts of accumulated mulch, after all the nitrogen had been spent by the $1963 / 64$ crop.

${ }^{4}$ In the same year, an ungrazed plot yielded 5.8 ton/ha following the plowing in of 4 years of accumulated sheep droppings.

monthly intervals from weaning to sale.

A subjective technique (0-5 scores) as suggested by Jeffries (1961) was used for estimating body condition.

Mating and lambing dates were recorded as well as disease and mortality of ewes, with causes of death whenever known. Details of lamb disposal and fate were also recorded.

\section{Results and Discussion}

\section{Primary Production}

Data on rainfall and on plant development are shown in Table 1. These yields are much higher than those indicated in some California reports from considerably higher rainfall areas (Hutchinson and Kotok, 1942; Heady, 1957 and 1961). The extreme variability of the rainfall is clearly demonstrated. Dry matter yields vary from 1 to 4 ton/ha in all but exceptional years. It may be seen that fluctuations in yield and dry matter herbage exceed the rainfall fluctuations by a factor of about $3: 1$. This is due to the all-important effect of rainfall distribution. Many small rains only wet the upper soil layers and a relatively large proportion of rain (up to $20-30 \%$ of the annual total) may be lost through direct soil surface evaporation. Too heavy rains may result in runoff or deep percolation beyond the root zone. For the mean total of $250 \mathrm{~mm}$ prevalent in this region, the ideal would seem to be a $100-\mathrm{mm}$ October-November rain, falling in 3-4 days, followed in monthly intervals by 3 or $450-\mathrm{mm}$ rains, each falling over a 2-3 day period till the middle of March. As an example of the influence of rainfall distribution, compare the consecutive years 1966/67 and 1967/68. The lower rainfall in 1966/67 with an almost ideal rainfall distribution resulted in optimal yields, whereas, due to recurring droughts in mid-season, the higher rainfall in 1967/68 yielded less.

\section{Fertilizer Application}

This annual vegetation reacts very strongly to fertilizer application. Fertilizer application may raise the total dry matter yield of the native pastures in all years 2 to 4 times (Tadmor et al., 1966-1970). Fertilizer application was not carried out in the grazing plots, but in small $(10 \times 10 \mathrm{~m})$ trial plots replicated 8-12 times. Fertilizer application was effective 
in all years, dry or wet. It was found that two thirds of the maximum response is reached with about $120 \mathrm{~kg} \mathrm{~N}$ applied as $\mathrm{NH}_{4} \mathrm{NO}_{3}$ or $\left(\mathrm{NH}_{4}\right)_{2} \mathrm{SO}_{4}$ per hectare. Maximal yields are at $200 \mathrm{~kg} \mathrm{~N} / \mathrm{ha}$. Fertilizer application is economic in wet years, when the basic yield is high. In such years pasture yields may be trebled to 8-15 tons/ha dry matter. In drought years, however, when yields are basically low, the immediate result is not economical notwithstanding the increase in yields. However, in this arid climate, the nitrogen fertilizer is not leached out of the root zone and remains stored in the soil till the following season or seasons. The soil can thus serve as a nitrogen bank; increased yields show up in subsequent years. Fertilizer application to the arid range under these conditions is always economically justifiable (Tadmor et al., 1970). These aspects form the basis of a current investigation into the nitrogen cycle of arid pastures. Disked-in sheep droppings can have the same effect as fertilizer.

\section{Lamb Production}

\section{Preliminary Trial (1964-1967)}

The key to economic pasture utilization lies in the proper assessment of an optimum stocking rate (Chisholm, 1965). The aim of the first experimantal stage was to arrive at an approximation of the carrying capacity of the area. Results of the third year of this stage (Table 2) show that production per animal was slightly higher under the lower stocking rate. The difference was, however, small and statistically not significant. The higher stocking rate resulted in a substantially higher production per unit pasture area (x 1.5). This conclusion formed the basis for the higher stocking rates applied during the second stage of the experiment.

\section{Main Phase (1967-1972)}

The interrelationship of rain, vegetation, body weight, and fertility will be dealt with in detail elsewhere. The present article will discuss only the main performance parameters.

Results are presented in Table 3 and Figure 5. The results dramatically demonstrate the complexity of the grazing system. Lamb yields are a product of fertility, lamb survival, and growth rate. All three vary with the stocking rate. However, other things being equal, fertility depends mainly on the body condition of the sheep during the breeding season, i.e., the preceding year. Lamb survival and growth rate depend on pasture conditions in the current year. The situation is further complicated by the diversity of rain distribution from year to year. To arrive at meaningful production figures, such an experiment must be run for several consecutive years.

It is thus pointed out that performance in the first year of the experiment is largely a result of the history of the sheep in the year before the onset of the experiment, so that true treatment effects actually begin to show from the second year on.

Table 2. Lamb production in $1966 / 67$ (third year of first stage).

\begin{tabular}{lcc}
\hline \hline & \multicolumn{2}{c}{ Stocking rate (ha/ewe) } \\
\cline { 2 - 3 } Parameter & 0.6 & 1.2 \\
\hline Lambing rate & 0.69 & 0.75 \\
Lamb's daily weight gain in the green season $(\mathrm{g})$ & 322 & 343 \\
Lamb yield/ewe $(\mathrm{kg})$ & 27.4 & 39.9 \\
Lamb yield/hectare $(\mathrm{kg})$ & 46 & 33 \\
\hline
\end{tabular}

There were two replicates to each stocking rate, 8 ewes in each replicate.

${ }^{2}$ Average number of lambs born per ewe in the flock.
Table 3. Sheep body weight (kg) fluctuations during $1968 / 69$ at different stocking rates (ha/head).

\begin{tabular}{llllll}
\hline \hline \multirow{2}{*}{$\begin{array}{c}\text { Stocking } \\
\text { rate }\end{array}$} & \multicolumn{5}{c}{ Month of weight recording } \\
\cline { 2 - 6 } & $12 / 68$ & $1-2 / 69^{1}$ & $5 / 69$ & $9 / 69$ & $12 / 69$ \\
\hline 0.2 & 39.3 & 43.6 & 56.4 & 47.2 & 41.0 \\
0.3 & 43.7 & 49.1 & 63.6 & 57.8 & 45.0 \\
0.4 & 45.8 & 47.6 & 63.0 & 57.3 & 46.5 \\
0.6 & 44.9 & 47.4 & 59.6 & 55.5 & 46.0 \\
0.8 & 49.7 & 51.8 & 62.2 & 63.7 & 52.5 \\
1.0 & 52.5 & 49.6 & 67.7 & 65.5 & 56.0 \\
\hline
\end{tabular}

13 days after lambing.

The years $1967 / 68$ to $1969 / 70$ were drought years of varying degrees; this accounted for a gradual overall reduction in productivity during this period. The $0.2 \mathrm{ha}$ /ewe plot was badly overgrazed and had to be discontinued after 2 years.

\section{Lambs Born per Ewe}

The average number of lambs born per ewe in the flock (Fig. 5) fluctuated considerably from year to year, particularly under the two extreme (lowest and highest) stocking rates. A least-square analysis of variance, however, has shown that the year effect was not significant. This may indicate that all year effects were of relatively little importance, at least at the beginning of the breeding season in August and September, and that real shortage of food occurred, during summer, only under the highest stocking rate of 0.2 ha/ewe.

The apparent "optimum curve" of fertility may be of true significance. The overall quadratic regression was highly significant $(P<0.01)$. Under the $1.0 \mathrm{ha} / \mathrm{ewe}$, the vegetation may have matured earlier than under heavier stocking rates, thus developing certain deficiencies. The ewes in this plot were very heavy (70-80 $\mathrm{kg}$ at the beginning of the breeding season). If this postulation is correct, then it may also explain a recovery of fertility, which was observed in 1970/71 following the 1970 drought, when probably less surplus feed was formed during the vegetation growing season.

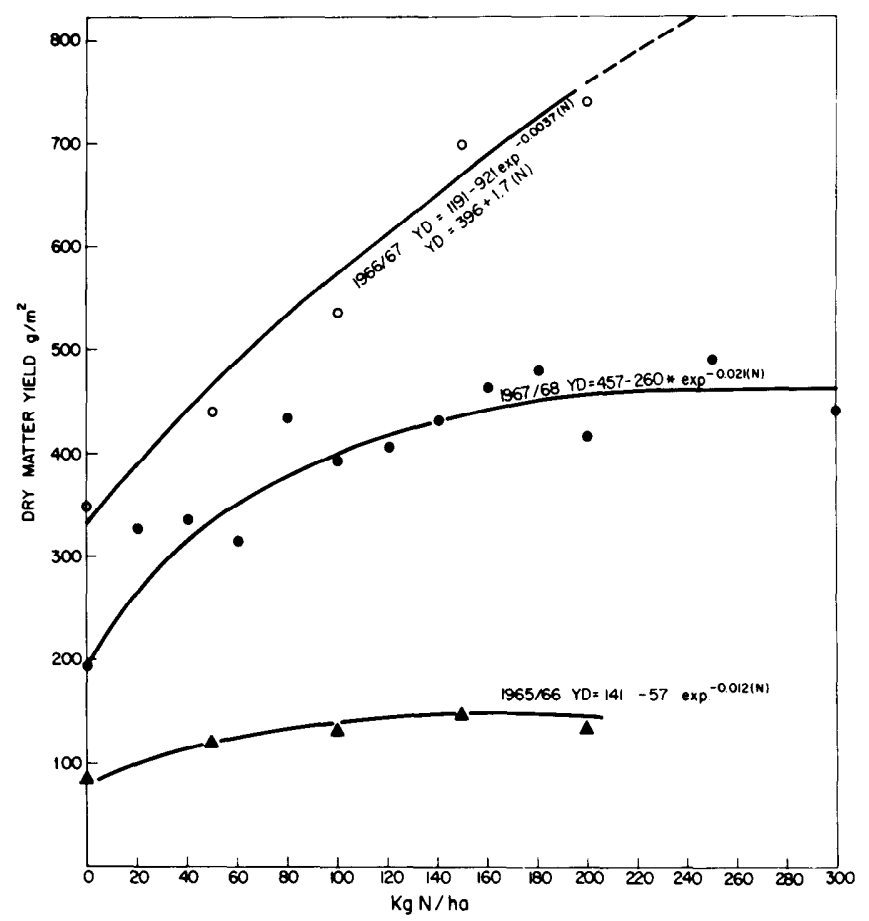

Fig. 5. Effects of fertilizer application on native pasture in 3 types of rainfall years. 


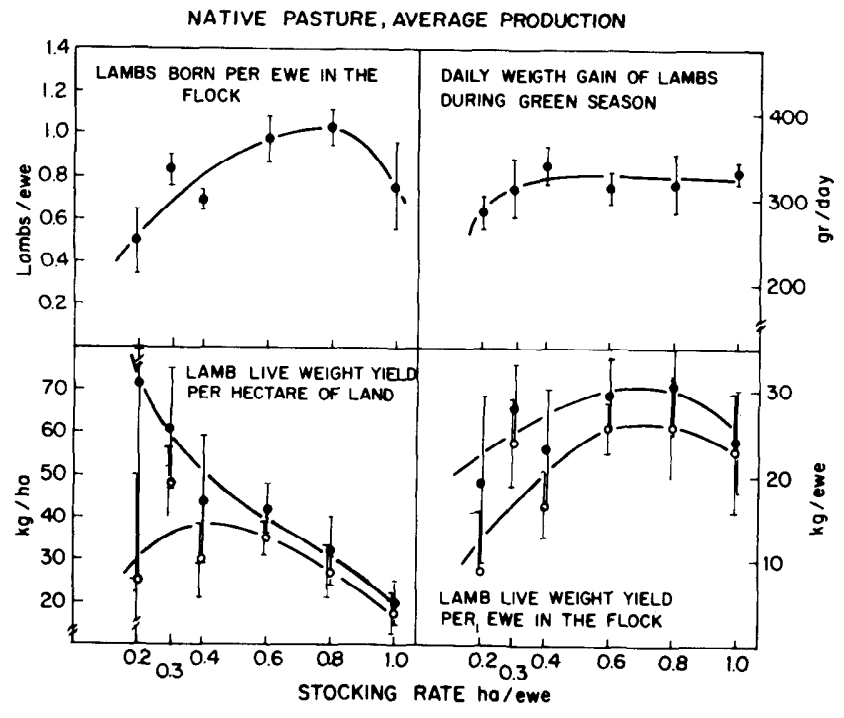

Fig. 6. Five years' average relationships between stocking rates and different parameters describing lamb production. (Full circles $=$ five years' averages; open circles = first year excluded.)

\section{Yield per Animal vs. Yield per Unit Area}

Within certain limits, yield per animal rises with reduced stocking rates, whereas yield per unit land area decreases. This is clearly demonstrated in the present results (Fig. 5). Optimum economic production depends on land/sheep value relationships and on prices of supplementary fodder. In high rainfall areas, land value is usually high and the optimum will, therefore, fall close to the point of maximum production per unit land area. The same may be true for a small country like Israel, where pasture lands are scarce and all land values are high. In other low rainfall areas land is cheaper and the optimum economic production will move closer to maximum production per animal.

In evaluating the results it must again be stressed, that those of the first year were greatly affected by the pre-experimental history of the sheep. All plots were grazed under relatively light stocking rates (first phase) and 1967 was one of the best years recorded in a long period. Results excluding the first year are, therefore, also given in Figure 5. A calculation of the optimum from the present experiment will have to await the accumulation of additional results. It seems, however, that with very limited supplementary feeding, the optimum will be close to $0.6-0.8 \mathrm{ha} / \mathrm{ewe}$. This is relatively high in comparison with similar rainfall areas in the world and may be explained by the high yield of the vegetation. Macfarlane (1968) cited much lower yields of dry matter per hectare for $250 \mathrm{~mm}$ rainfall areas. It is impossible to compare the results of lamb production with those appearing in literature, as all the available reports on lamb production deal with areas of higher rainfall.

The low per-ewe yields in 1968/69 and in 1969/70 are partly due to the fact, that during these drought years it was feared that the lamb burden would endanger the subsequent ewe fertility to a degree that would mask stocking rate effects. It was, therefore, decided to transfer a number of the lambs immediately after birth to an artificial rearing unit and, in these cases, both ewe and plot were credited only with the newly born lamb. The lambs that were left to be suckled showed that the pasture (and the ewes) could easily support the production of $15-20 \mathrm{~kg}$ lambs, (weaning at 6-8 weeks). In the succeeding seasons only mismothered lambs were sent to the artificial rearing unit.

The present experiment was made to assess the unsupported productive capacity of the area. No supplementary feeding was given and no management manipulations were made. Productivity of the area concerned would probably be greatly increased by various means such as the introduction of a more fertile breed of sheep, together with appropriate management procedures, i.e., supplementary feeding during late pregnancy and artificial rearing and early weaning of the lambs.

\section{Literature Cited}

Arnold, G. W. 1960. The effect of the quantity and quality of pasture available to sheep on their grazing behavior. Aust. J. Agr. Res. 11:1034-1043.

Benjamin, R. W., A. A. Degen, A. Brieghet, and H. Takhan. 1973. The determination of feed intake under grazing conditions from the water turnover of sheep. Symposium on Water-Animal Relations, Kimberley, Idaho, ed. H. F. Mayland. p. 83-94.

Butzer, K. W. 1951. Climatic changes in the arid regions since the Pliocene. In: History of Land Use in Arid Regions. Arid zones research. XVII, UNESCO, Paris, p. 31-58.

Chisholm, A. H. 1965. Towards the determination of the optimum stocking rate in the high rainfall zone. Rev. of Marketing and Agr. Econ. (N.S.W. Dep. Agr:) Vol. 33, No. 1.

Heady, H. F. 1957. Effect of cages on yield and composition in the California annual type. J. Range Manage. 10:175-177.

Heady, H. F. 1961. Specialized grazing systems, A review and applications to the California annual type. J. Range Manage. 14:182-193.

Hillel, D. 1959. Studies on Loessial Crusts. Bull. Agr., Res. Sta. Rehovot, Nr. 63.

Hutchinson, C. G., and E. I. Kotok. 1942. The San Joaquin experimental range. Univ. of Calif., Berkeley, Bull. 663, p. 32-33.

Jeffries, B. C. 1961. Body condition scoring and its use in management. Tas. J. Agr. 32:19-21.

Levi, W. N. 1963. The dry winter of $1962 / 63$, a synoptic analysis. Israel Explor. J. 13:229-241.

Lyne, A. G., M. Jolly, and D. E. Hollis. 1970. Effects of experimentally produced local subdermal temperature changes on skin temperature and wool growth in the sheep. J. Agr. Sci. Camb. 74:83.

Macfarlane, W. V. 1968. Protein from the wasteland. Aust. J. Sci. 31:20-30.

Purohit, G. R., P.K. Ghosh, and G. C. Taneja. 1972. Water metabolism in desert sheep. Aust. J. Agr. Res. 23:685-91.

Roe, R., W. H. Southcott, and Helen Newton Turner. 1959. Pasture and sheep production with special reference to systems of grazing and internal parasites. Aust. J. Agr. Res. 10:530-554.

Rossiter, R. C. 1966. Ecology of the Mediterranean annual type pasture. Adv. Agron. 18:1-56.

Shanan, L., M. Evenari, and N. H. Tadmor. 1967. Rainfall pattern in the Negev Desert. Israel Explor. J. 17:163-84.

Tadmor, N. H., R. Benjamin, and Y. Gutman. 1966-1970. Fertilizer application to arid range. I. 1965/66. II. 1966/67. III. 1967/68. IV. 1968/69. Prelim. Rep. Nat. Univ. Inst. Agr. Rehovot, Israel.

Tadmor, N. H., E. Eyal, R. W. Benjamin, N. Seligman, B. Yogev, and L. Shanan. 1963-1971. Seeded dryland range in the Northern Negev of Israel. Progr. Rep. 1-5. Agr. Res. Org., Beit Dagan. (Hebrew with English summaries)

Tadmor, N. H., D. Hillel, and Y. Cohen. 1968. Establishment and maintenance of seeded dryland range under semi-arid conditions. Final Rep., U.S. Dep. Agr. Project A10-CR-45. p. 141.

Tadmor, N. H., and D. Lachover. 1967. Variations saissonnieres de la composition alimentaire des differents types de paturage de Neguev septentrional d'Israel. Qual. Plant. Mat. Veg. 15:37-47.

Tadmor, N. H., and L. Shanan. 1969. Runoff inducement in an arid region by removal of vegetation. SSSAP 33:790-793.

Trumble, H. C. 1952. Grassland agronomy. Advanc. in Agron. 4:1-65.

Willoughby, W. M. 1959. Limitations to animal production imposed by scasonal fluctuations in pasture and by management procedures. Aust. J. Agr. Res. 10:248-268. 